\title{
Fiatalok életcéljai és munkavállalási tervei egy kelet-magyarországi vizsgálat tükrében
}

\author{
R. Fedor Anita ${ }^{1}$, Engler Ágnes ${ }^{2}$, Markos Valéria ${ }^{3}$ \\ 1.főiskolai tanár, intézetigazgató, Debreceni Egyetem Egészségügyi Kar, Szociális és Társadalomtudományi Intézet, \\ 4400 Nyíregyháza, Sóstói út 2-4. \\ 2.egyetemi docens, Debreceni Egyetem Nevelés és Művelődéstudományi Intézete, 4032 Debrecen, Egyetem tér 1 \\ 3.PhD hallgató Debreceni Egyetem Humán Tudományok Doktori Iskola Nevelés és Művelődéstudományi Program, \\ 4032 Debrecen, Egyetem tér 1
}

\begin{tabular}{|c|c|}
\hline INFO & ABSTRACT \\
\hline $\begin{array}{l}\text { Anita R. Fedor } \\
\text { fedor.anita@foh.unideb.hu }\end{array}$ & \multirow[b]{2}{*}{$\begin{array}{l}\text { Youngsters' life goals and work plans in the light of an } \\
\text { East-Hungarian study. In our research project we embarked } \\
\text { on surveying the visions, ideas, further education plans, } \\
\text { career plans and objectives of the young people of Nyíregy- } \\
\text { háza. We wanted to find out what short- and long-term plans } \\
\text { the young people have for the period when they have } \\
\text { completed the secondary school, and what value preferences } \\
\text { are coupled with their plans. In the course of our research we } \\
\text { wished to examine the vision of the future of the secondary } \\
\text { school students in a three-dimensional way: their visions of } \\
\text { their own private and professional future were complemented } \\
\text { with an analysis of their value preferences. In general, it is } \\
\text { clear from the results that the visions of the students related } \\
\text { to work and career are more clearcut and optimistic than their } \\
\text { ideas regarding the future of their private life. }\end{array}$} \\
\hline $\begin{array}{l}\text { Keywords } \\
\text { youth, } \\
\text { employment, } \\
\text { private life plan, } \\
\text { value preferences }\end{array}$ & \\
\hline $\begin{array}{l}\text { Kulcsszavak } \\
\text { fiatalok, } \\
\text { munkavállalás, } \\
\text { magánéleti tervek, } \\
\text { értékpreferenciák }\end{array}$ & $\begin{array}{l}\text { Absztrakt: Tanulmányunkban a nyíregyházi középiskolások } \\
\text { továbbtanulásával, munkavállalásával, életcéljaival kapcsola- } \\
\text { tos elképzeléseinek, jövőbeli terveinek feltérképezését vál- } \\
\text { laltuk. Arra kerestük a választ, hogy az érintett tanulóknak } \\
\text { milyen rövid- és hosszútávú céljaik vannak a középiskolai ta- } \\
\text { nulmányok befejezését követően, és ehhez milyen értékprefe- } \\
\text { renciák társulnak. A kutatás során megkérdezett nyíregyházi } \\
\text { fiatalok jövő-képét háromoldalú egységben igyekeztünk kör- } \\
\text { bejárni: a szakmai és magánéleti tervek vizsgálatát kiegészí- } \\
\text { tettük az értékpreferenciák elemzésével. Az eredmények } \\
\text { alapján összességében elmondható, hogy a munkával, karri- } \\
\text { errel összefüggó terveik világosabbak és optimistábbak, mint } \\
\text { a magánéleti életút-elképzelés. }\end{array}$ \\
\hline
\end{tabular}




\section{Bevezetés}

Írásunkban a nyíregyházi középiskolások körében lebonyolított empirikus munkánk eredményeit mutatjuk be. Vizsgálatunkban az érintett fiatalokat arról kérdeztük meg, hogy hogyan gondolkodnak a továbbtanulásukról, milyen elképzeléseik vannak a későbbi munkavállalásukat illetően, s hogy melyek a legfőbb életcéljaik.

Tanulmányunk első részében a munka és jövő kapcsolatára figyeltünk. A munkaerö-piaci helyzetük bemutatásán túl arra is kíváncsiak voltunk, hogy milyen elvárásaik vannak jövőbeli munkahelyükkel szemben, s hogyan vélekednek a sikeres elhelyezkedést meghatározó tényezőkről. A munka- és karrierterveket követően a magánéleti terveket kíséreltük meg feltérképezni a rendelkezésre álló adatok alapján. A tanulmány harmadik részében a fiatalok értékpreferenciáit vizsgáltuk meg szoros összefüggésben a munka és magánélet világával.

Elemzésünk alapját a Youth in the Central and Eastern European Cross-border Areas nemzetközi projekt keretében, 2015-ben lebonyolított kérdőíves adatfelvétel adta. A kutatás alapsokaságát a lengyel, ukrán és magyar határ menti térség egy-egy nagyvárosában élő érettségi előtt álló gimnazista és középiskolás fiatalok alkották. A végleges hazai mintába a nyíregyházi gimnáziumok és szakközépiskolák közül öszszesen öt intézmény 359 fö 11. évfolyamos diákja került be. Jelen írásunkban ezen tanulók továbbtanulási, munkavállalási, bizalmi attitüdjét, valamint értékpreferenciáit mutatjuk be. Elemző munkánkban további kutatások eredményeit is felhasználtuk.

\section{Munkaerö-piaci jövőkép}

Napjainkban a munka fogalma átalakulóban van (vö. pl. Rimler 1999, Forgó et al. 2009, Kiss és Répáczky 2012). Kezdetben a munka elsődleges célja a termelés, az anyagi-, fogyasztási javak és szolgáltatások előállítása volt, az idők során a munka a társadalomba való integrálódás egyik eszközévé vált. Napjainkban egyre inkább felértékelődtek az olyan egyéni készségek és képességek, mint az idegen nyelv ismerete, a kommunikációs készség, informatikai ismeretek, nagyfokú munkaterhelhetőség, önállóság, elhivatottság, motiváció és készség a csapatmunkában stb. A mindezeknek való megfelelés nagy kihívás elé állítja a fiatalokat, így sokan úgy próbálnak megfelelni a munkaadók elvárásainak, hogy már tanulmányaik folytatás közben kipróbálják magukat a munkaerőpiacon.

Egy tanulmányait folytató középiskolai diák számára a munkaerőpiacra való becsatlakozásra négy lehetősége nyílik: a szakmai gyakorlat, az iskolai közösségi szolgálat, a fizetett munka, vagy az önkéntes munka által. Az, hogy az egyén melyik munkaformát választja jelentős mértékben függ a munka motivációjától. Míg a szakmai gyakorlat és a közösségi szolgálat kötelező jellegü, addig a fizetett és önkéntes munkát szabad akaratából vállalja az egyén. Míg a fizetett munka célja elsősorban a pénzszerzés, az önkéntes munkáé lehet tradicionális vagy individualista motivációjú egyaránt (Fényes és Kiss 2011, Markos 2016a). 
Tanulmányunk ezen részében arra keressük a választ, hogy a nyíregyházi középiskolások milyen munkaerőpiaci tapasztalattokkal, elvárásokkal és jövőképpel rendelkeznek és mit gondolnak arról, hogy milyen készségek és képességek szükségesek ahhoz, hogy az életben sikereket érhessenek el.

\section{A középiskolás diákok korábbi munkatapasztalatai}

Elsőként azt vizsgáltuk, hogy a nyíregyházi középiskolás diákok milyen korábbi munkatapasztalatokkal rendelkeznek, és milyen típusú tevékenységet végeztek tanulmányaik alatt, illetve szünidőkben. A diákok többsége (35\%-a) önkéntes munkát és szerződéssel járó alkalmi fizetett munkát (26\%) végzett. A diákok kisebb hányada végzett nem legális munkát $(9 \%)$, teljes vagy részmunkaidős munkát $(6 \%)$, illetve olyan szakmai gyakorlatot, amiért pénzbeli fizetség járt (3\%). A diákok $10 \%$ az általunk felsoroltakon kívül más típusú munkát végzett, míg 11\%-a semmilyen munkát nem végzett élete során.

Magyarországon 2011-ben bevezetésre került az iskolai közösségi szolgálat, mely az érettségi megszerzésének alapkövetelményévé vált. A közösségi szolgálat fő célja, hogy növelje a középiskolás diákok állampolgári tudatosságát, motiválja öket a jövőbeni önkéntességre, elősegítse a tolerancia és a segítő szándék kialakulását, valamint könnyítse a pályaorientációjukat. Az kvantitatív adatok azt mutatják, hogy a diákok legnagyobb aránya önkéntes munkát végzett, melynek fő oka az lehet, hogy jelenleg a közösségi szolgálat kiforratlanságából adódóan a közéletben gyakran téves definíciók fordulnak elő a szolgálattal kapcsolatban, így maguk a diákok is gyakran azonosítják a közösségi szolgálatot az önkéntes munkával (Markos 2016b).

Szignifikáns az összefüggés a nem és a munkavégzés között. Az adatok szerint, a lányok nagyobb arányban végeztek önkéntes munkát, míg a fiúk a fizetett munkát részesítették előnyben. ${ }^{1}$ Ez az eredmény párhuzamban áll Kóródi $(2006,2007)$ eredményeivel, (ő a felsőoktatási hallgatók munkaértékeit vizsgálta) mely szerint a nők számára fontosabb, hogy a végzett munka társadalmilag hasznos legyen és a munka által segíthessen másokon, míg a férfiak számára a magas kereset, a munkahelyi előrejutás és az önálló munkavégzés a fontosabb.

Vizsgálatunkban a diákok 16\%-a a szociális szolgáltatások területén, 15\%-a a kereskedelemben, 14\%-a reklámiparban, 14\% szolgáltatások területén, 12\%-a a mezőgazdaságban, $10 \%$ az árutermelésben, $7 \%$ az építkezésben, $3 \%$ a közétkeztetésben és további $8 \%$ az egyéb területen dolgozott.

A következőkben azt vizsgáltuk, hogy a diákok számára mit jelent a munka (néhány a kérdőívben felsorolt állítás közül kellett kiválasztania azt az egyet, amellyel leginkább egyetért.) A válaszadó diákok fele szerint (51\%) a munka elsősorban pénzszerzési lehetőség és a különböző igények kielégítésére szolgál. A diákok 22,7\%-a szerint elsősorban azok találnak munkát, akik akarnak dolgozni, 13,3\%-uk szerint a munka az a tevékenység, mely elégedettséggel tölti el az egyént, és 10,2\%-uk szerint

\footnotetext{
${ }^{1}$ A nők 34,8\%-a önkéntes munkát, 32,3\% alkalmi munkát, 15,2\% nem dolgozott, 7,1\% másfajta munkát, $4 \%$ fizetett szakmai gyakorlatot, 3,5\% teljes vagy részmunkaidős munkát, 3\% nem legális munkát végzett. A férfiak 35,2\% alkalmi munkát, 21,4\% önkéntes munkát, 11,7\%a nem legális munkát, $11,7 \%$-a nem dolgozott, 11\% másfajta munkát, $6,2 \%$ teljes vagy részmunkaidős munkát és $2,8 \%$ fizetett szakmai gyakorlatot végzett.
} 
minden ember kötelessége, hogy dolgozzon. A válaszadók csak kis hányada $(2,8 \%$ uk) nyilatkozott úgy, hogy a munka a legfontosabb dolog az életben.

A munkával kapcsolatos állítások összefüggéseit vizsgáltuk más háttérváltozókkal is (nem, lakóhely településtípusa, szülők iskolai végzettsége, munkahelyi beosztása, a család anyagi helyzete), azonban szignifikáns összefüggés a változók között nem volt kimutatható.

\section{A diákok munkaerő-piaci jövőképe}

A diákok többsége úgy nyilatkozott, hogy a munka elsősorban pénzszerzési lehetőség (lásd: előző fejezet), így megvizsgáltuk, hogy mennyi az az összeg, amiért hajlandóak lennének munkába állni; valamint, hogy mennyi az az összeg, amivel elégedettek lennének. (1. táblázat)

\begin{tabular}{|l|l|l|}
\hline & Összeg, amiért munkába állna & Összeg, amivel elégedett lenne \\
\hline $0-99.999 \mathrm{Ft}$ & 8,6 & 7 \\
\hline $100.000-199.999 \mathrm{Ft}$ & 48,7 & 18,1 \\
\hline $200.000-299.999 \mathrm{Ft}$ & 24,2 & 30,4 \\
\hline $300.000-399.999 \mathrm{Ft}$ & 11,4 & 12,8 \\
\hline $400.000 \mathrm{felett}$ & 7 & 31,8 \\
\hline Összesen & $359(100 \%)$ & $359(100 \%)$ \\
\hline
\end{tabular}

1. táblázat. A havi bér összege (Ft-ban), amiért munkába állna és amivel elégedett lenne (\%-ban). $(\mathrm{N}=359)$

A diákok többsége számára a száz és kétszázezer forint az az összeg, amit elfogadna (48,7\%), azonban négyszázezer forint és a feletti az az összeg, amivel elégedett is lenne $(31,8 \%)$. A kérdést tovább vizsgálva - néhány szocio-demográfiai háttérváltozó bevonásával - szignifikáns összefüggés mutatható ki azon összegek között, amit a diák elfogadna és amivel elégedett lenne, valamint az édesapa iskolai végzettsége és a család anyagi helyzete között. Az eredmények azt mutatják, hogy minél magasabb az apa iskolai végzettsége, annál magasabb az az összeg, amit a diákok elfogadnának és elvárnának, valamint a jobb anyagi helyzetü családok gyermekei magasabb jövedelmet várnak el és magasabb összeggel elégednének meg, mint a rosszabb anyagi helyzetü társaik.

A munkaerő-piaci jövő tekintetében arra is kíváncsiak voltunk, hogy a fiatalok melyik szférában képzelik el magukat, mint munkavállalók. A válaszadók közel egynegyede a saját üzleti vállalkozásban, s közel ugyanennyien (24,7\%) a biztonságosnak tekinthető állami szférában kíván elhelyezkedni a diploma megszerzését követően. A következő legnépesebb tábor (17,7\%) külföldi cégeknél való munkavállalás lehetőségében gondolkodik, s 16\%-ukat a külföldi munkavállalás motiválja. Ennél jóval kevesebben szeretnének családi vállalkozásban $(6,1 \%)$, magánszektorban alkalmazottként (5,8\%), valamint egyéb típusú (5,5\%) munkahelyen dolgozni a felsőfokú tanulmányok után.

Következő lépésben arra kértük a megkérdezetteket, hogy gondolják végig, hogy egy esetleges cégalapítást milyen főbb tényezők motiválnák. Válaszadóink meghatározó többsége a saját valamint a család megélhetésének biztosítása vezérelné abban az esetben, ha saját céget alapítana. A magas jövedelem elérésének a lehetősége a 
fiatalok közel egyötödénél játszana szerepet, s ennél kevesebben $(11,8 \%)$ vélekednek úgy, hogy a képességek kibontakozását szavatolhatja a saját cég létesítése. A függetlenség és önállóság, mint motivációs tényező a mintában szereplők 8,4\%-át jellemezte. A település számára történő haszontermelés és az egyéb válaszlehetőségek aránya alig haladta meg az egy százalékot.

A következőkben a hallgatók szakmabeli terveire voltunk kíváncsiak. A megkérdezettek majdnem fele (44,9\%) olyan stabil és megbízható munkára vágyik, amit akár a munkahelyen akár otthon végezhet (távmunka, internet, számítógép vagy mobil szolgáltatás igénybevételével). A diákok további egy negyed (26,3\%) olyan munkát szeretne, mely stabil és megbízható, azaz a mindennapi munkáját ugyanabban az időben és ugyanazon a helyen végezheti. A megkérdezettek 17,2\%-a teljes munkaidős állást szeretne, mely a lehetséges legtöbb keresettel jár együtt, míg további $6,8 \%$-a olyat, ami otthon is végezhető és amely független az időtartamtól és a munkaszerződés típusától. A diákok mindössze 1,7\%-a vágyik olyan munkára, amely ideiglenes munkaszerződéssel jár, 3,1\%-uk pedig az általunk felsoroltakon kívül más munkát szeretne.

A nemek tekintetében megállapítható, hogy szignifikáns összefüggés van a nem és a szakmabeli tervek között. ${ }^{2}$ A nők $48,2 \%$-a olyan munkát szeretne, amit otthon is végezhet, további $25,9 \%$-a pedig olyan munkát, amit ugyanabban az időben, ugyanazon a helyen végezhet. A 16,2\%-uk teljes munkaidőben végezhető munkát, 4,1\%-uk otthon végezhető munkát szeretne, mely független az időtartamtól és a munkaszerzödés típusától. További 2\%-uknak ideiglenes munkaszerződéses és 3,6\%-uknak egyéb elképzelései vannak a jövendöbeli munkájukról. A férfiak 39,3\%-a otthon is végezhető, 28,3\%-a pedig olyan munkát szeretne, amit ugyanabban az időben, ugyanazon a helyen végezhet. További 19,23\%-uk teljes munkaidőben végezhető, 11\%-uk kizárólag otthoni munkát vállalna. A férfiak között nem voltak olyan diákok, akik ideiglenes munkaszerződéses munkát vállalnának. A megkérdezett férfiak 2,1\%-ának egyéb elképzelései vannak a jövendőbeli munkájukról.

Mivel a nők kevesebb időt tudnak a gyermeknevelés és otthoni feladataik miatt a munkaerőpiacon tölteni, elsősorban az olyan atipikus munkaformákat részesítik előnyben, melyet nem csak a munkahelyen, hanem akár otthon is végezhetnek. Ezzel szemben a férfiak elsősorban olyan munkára vágynak, amit minden nap ugyanabban az időben, ugyanazon a helyen végezhetnek. Fontos számukra a teljes munkaidő és a magas kereset, de a nőkhöz képest sokkal inkább előnyben részesítik az olyan időtartamtól és munkaszerződéstől független munkát, ami otthon végezhető. Míg a férfiak jövőképében nem jelenik meg az ideiglenes munkaszerződéssel járó munka, addig a megkérdezett nők 2\% elfogadna ideiglenes munkaszerződéssel járó állást is.

Következtetéseink párhuzamban állnak Fényes (2010) következtetéseivel, aki a felsőfokú intézményen hallgató diákok munkaattitüdjeit vizsgálta. Eredményei szerint a lányok nagyobb arányban lennének hajlandóak részmunkaidős vagy bármilyen munkát elvállalni, hisz tudatában vannak rosszabb munkaerőpiaci kilátásaikkal és későbbi otthoni feladataikkal, valamint pesszimistábbak elhelyezkedési esélyeikkel kapcsolatban.

\footnotetext{
${ }^{2}$ Szintén szignifikáns összefüggés mutatható ki a szakmabeli tervek és a településtípus között, azonban terjedelmi korlátok miatt az adatok bemutatásától most eltekintünk.
} 
Meg kell jegyeznünk, hogy egy 2015-ben a nyíregyházi fiatalok körében végzett kutatás szerint a fiatalok 34\%-a kedvezőtlennek, vagy nagyon kedvezőtlennek ítéli meg a munkavállalással kapcsolatos kilátásait és mindössze a fiatalok $26 \%$-a bízik abban, hogy könnyen munkát talál majd (Kállai et al. 2016).

Végül arról kérdeztük a diákokat, hogy véleményük szerint mi járul hozzá a sikeres élethez a mai társadalomban. Mivel a fontossági sorrendre nem kérdeztünk rá és választásukat maximum öt lehetőségre korlátoztuk, csak azt tudjuk meghatározni, hogy milyen kompetenciákat jelöltek a legtöbben (1. ábra).

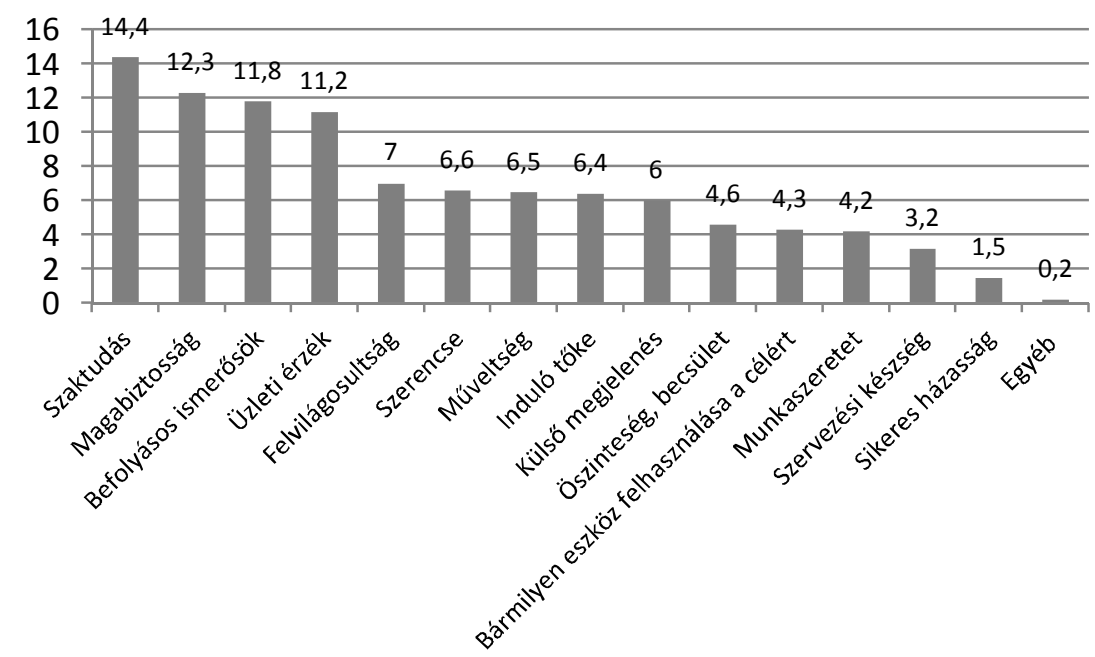

1. ábra. A sikeres élethez szükséges kompetenciák. ( $\mathrm{N}=1532)$

A diákok többsége elsősorban a szaktudás és szakértelem fontosságát tartotta a legfontosabbnak az érvényesülésben, majd ezt követte a magabiztosság és önbizalom; a befolyásos baráti, ismerősi, rokoni kapcsolatok; az üzleti érzék, a vállalkozói kedv, a kockázatvállalási hajlandóság, valamit a felvilágosultság és a sokrétü szakmai tudás.

A 2012-es Ifjúság kutatás is hasonló eredményekről számolt be (Czibere 2014, Gazsó 2013). Az országos adatok szerint elsősorban a szaktudás, a hozzáértés, valamint a protekció szerepét hangsúlyozták a fiatalok, melyek nélkülözhetetlenek az elhelyezkedéshez. Az érvényesüléshez azonban egy biztos munkahely, a jó kapcsolatok, összeköttetések, ismeretségek, valamint akaraterő és ambíció szükséges. A rangos végén a jó modor, a vállalkozó szellem, a számítógépes ismeretek, az ügyeskedés, a szerencse és az erőszakos magatartás állt.

A munkaerő-piaci érvényesülést számos tényező befolyásolja. A megszerzett legmagasabb iskolai végzettséget, a munkaerö-piaci tapasztalatot, a településtípust, stb. Azonban a kapcsolati tőkének, a személyes kapcsolatok mozgósításának fontosságát is ki kell emelni. Az informális információáramlás, valamint az álláskeresési technikák ismerete segítséget jelenthet egy-egy potenciális álláslehetőség betöltéséhez. A Nyíregyházi járásban élő felnőttek körében végzett vizsgálat eredményei szerint a megkérdezettek több mint fele személyes ismeretsége útján jutott jelenlegi állásához 
(R. Fedor és Balogh 2015). A Magyar Ifjúság 2012 kutatásban szintén igen jelentősnek ítélték a fiatalok a kapcsolatok munkaerö-piaci értékét, ugyanis négyötödük 4esre és 5-ösre értékelte (ötfokozatú skálán) a kapcsolati tényezők fontosságát. A protekcióban az említett fiatalok háromnegyed bízott (Gazsó 2013). Saját vizsgálatunkban arra voltunk kíváncsiak, hogy „Hogyan gondolja, elsősorban mi befolyásolja egy állás megszerzését a tanulmányok befejezése után? A 2. számú táblázat adatiból látható, hogy a válaszadók az elhelyezkedés szempontjából az idegennyelvtudást $(72,2 \%)$ tartják magasan a legfontosabbnak. ${ }^{3}$ Ezt követi a fontossági sorrendben a magas szintü szakmai tudás, ismeretek és készségek (52,\%), az ismeretség, protekció (48,9\%), a megjelenés, kisugárzás (48,5\%), a szorgalom és kemény munka (46,4\%), a megszerzett végzettség (43,9\%) kategóriája. Ami talán meglepő lehet, az az, hogy összességében a külső megjelenés az ismeretség és protekció egyenértékü a szorgalom és kemény munka, a megszerzett végzettség valamint a magas szintü szakmai tudás szerepével. A fiatalok szubjektív megítélése szerint a munkaerö-piaci érvényesülés szempontjából a legkevésbé meghatározó dimenziók a szülök anyagi helyzete $(15,7 \%)$ és a politikai nézetek $(14,3 \%)$.

\begin{tabular}{|l|c|c|c|c|c|}
\hline & $\begin{array}{c}\text { Határo- } \\
\text { zottan } \\
\text { igen }\end{array}$ & $\begin{array}{c}\text { In- } \\
\text { kább } \\
\text { igen }\end{array}$ & $\begin{array}{c}\text { In- } \\
\text { kább } \\
\text { nem }\end{array}$ & $\begin{array}{c}\text { Határo- } \\
\text { zottan } \\
\text { nem }\end{array}$ & $\begin{array}{c}\text { Nem tu- } \\
\text { dom/nem vá- } \\
\text { laszolok }\end{array}$ \\
\hline 12.1. Ismeretség, protekció & $\mathbf{4 8 , 9}$ & 44,4 & 5,0 & 1,7 & 0,0 \\
\hline $\begin{array}{l}\text { 12.2. Magas szintú szakmai tu- } \\
\text { dás, ismeretek és készségek }\end{array}$ & $\mathbf{5 2 , 0}$ & 41,6 & 5,3 & 1,1 & 0,0 \\
\hline 12.3. A megszerzett végzettség & $\mathbf{4 3 , 9}$ & 45,8 & 8,4 & 0,8 & 1,1 \\
\hline $\begin{array}{l}\text { 12.4. Kezdeményezó- és vállal- } \\
\text { kozókészség }\end{array}$ & 27,3 & 55,4 & 14,8 & 1,7 & 0,0 \\
\hline 12.5. A szülők anyagi helyzete & 15,7 & 28,9 & 42,6 & 12,3 & 0,6 \\
\hline $\begin{array}{l}\text { 12.6. A választott munkaterület, } \\
\text { foglalkozás }\end{array}$ & 27,6 & 56,1 & 14,2 & 0,9 & 1,1 \\
\hline $\begin{array}{l}\text { 12.7 Szorgalom és kemény } \\
\text { munka }\end{array}$ & $\mathbf{4 6 , 4}$ & 41,6 & 10,1 & 1,1 & 0,8 \\
\hline 12.8. Lakhely & 20,3 & 38,6 & 29,9 & 10,7 & 0,6 \\
\hline 12.9. Ravaszság, találékonyság & 37,1 & 42,5 & 15,9 & 4,2 & 0,3 \\
\hline 12.10. Szerencse & 27,6 & 41,1 & 24,5 & 5,9 & 0,8 \\
\hline $\begin{array}{l}\text { 12.11. Társadalmi háttér, szár- } \\
\text { mazás }\end{array}$ & 21,6 & 42,9 & 27,6 & 7,1 & 0,9 \\
\hline $\mathbf{1 2 . 1 2}$ Megjelenés, kisugárzás & $\mathbf{4 8 , 5}$ & 42,9 & 6,4 & 2,2 & 0,0 \\
\hline 12.13. Politikai nézetek & 14,3 & 27,1 & 39,1 & 19,5 & 0,0 \\
\hline $\begin{array}{l}\text { 12.14. Az intézmény presztízse, } \\
\text { ahol tanulmányait végezte }\end{array}$ & 26,7 & 52,0 & 18,2 & 2,6 & 0,6 \\
\hline 12.15. Idegennyelvtudás & $\mathbf{7 2 , 2}$ & 24,4 & 2,5 & 0,8 & 0,0 \\
\hline
\end{tabular}

Forrás: Nyíregyházi középiskolások, 2015. (N=354)

2. táblázat. Hogyan gondolja, elsősorban mi befolyásolja egy állás megszerzését a tanulmányok befejezése után? (százalékos megoszlások).

${ }^{3}$ A ,Hogyan gondolja, elsősorban mi befolyásolja egy állás megszerzését a tanulmányok befejezése után?” kérdésre ,határozottan igen” választ adtak. 


\section{Magánéleti jövőkép}

A kutatás a fiatalok következő életszakaszait tekintve elsődlegesen a továbbtanulásra, munkavállalásra koncentrált, azonban néhány kérdés felvetette a magánéleti elképzeléseket is. Ezek a párkapcsolatra és gyerekvállalásra vonatkoztak. A rendelkezésre álló adatok alapján megkíséreltük megfejteni a fiatalok családlapítással összefüggésbe hozható elképzeléseit és attitüdjét.

\section{A párkapcsolat és a családi élet}

Amint az előző fejezetben láttuk, a mai társadalmi körülmények között a sikeres élethez számos feltételt szükségesnek éreznek a fiatalok (elötérbe helyezik a szaktudást, szakértelmet, az üzleti érzéket, a tulajdonságok között a magabiztosságot, elhivatottságot). Hangsúlyosan megjelenik a befolyásos ismerősök szükségessége, ugyanakkor a sikeres házasság a hosszú sor végén szerepel. Ez jól mutatja, hogy a tinédzserek bizalmi tókéjüket a lazább, de sikerrel kecsegtető kapcsolatokba helyezik, nem sejtve a későbbi (tapasztaltabb) életkorban már felismert magánéleti háttér fontosságát. (Putman 2000, Pikó 2003) A stabil párkapcsolatok biztos hátteret nyújtanak az egyéni karrier kibontakozásához, értve ezalatt az emberi tőkébe fektetett időszakokat (tanulás, képzés) és a munkában történő előrehaladást (karrierépítés). (Kopp és Skrabski 1995, Balog 2008, Engler 2011)

A kérdőívben szerepelt egy olyan kérdés, amely a válaszadók különböző esélyeit a szüleik generációjához képest mérten latolgatta (Összehasonlítva szülei generációjával, milyen esélyei vannak az alábbiakban felsorolt életcélok megvalósításában?). A megadott szempontok mindegyike a jövőbe tekint, hiszen a munkában és a magánéletben elérendő célokra kérdez rá. A 2 . ábrán jól látható, hogy az utóbbi életszférát tekintik kevésbé megvalósíthatónak (vagy másképp megvalósulónak) a szülők privát életútjához képest.

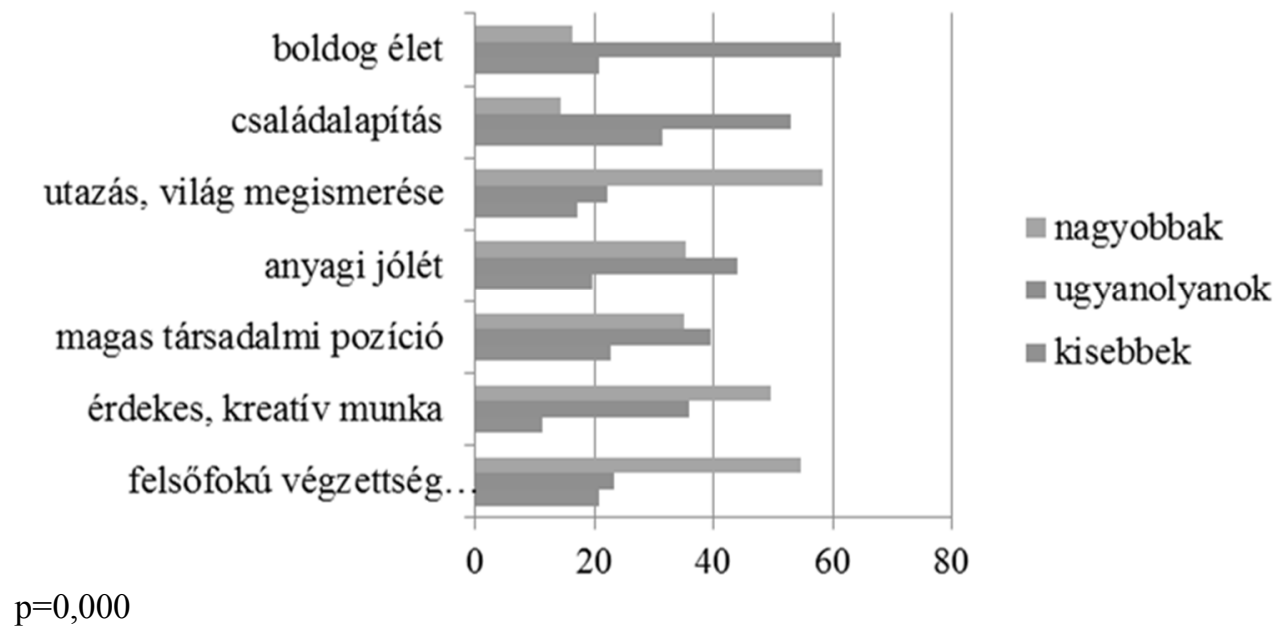

2. ábra. Életcélok elérésének esélye a szülők generációjához képest (százalék). 
A válaszadók harmada nyilatkozott úgy, hogy a családalapításra kisebb esélyei vannak, mint elődjeinek, e tekintetben a leginkább szkeptikusak a fiatalok (más tényező nem ért el ilyen alacsony esélybecslést). Emögött természetesen a megváltozott életút-mintázat tudatossága rejlik, hiszen még egy generációval korábban is a tanulást követően a családalapítás és a munkavállalás párhuzamos életesemény volt. A megváltozott demográfiai magatartás szoros összefüggésben áll az iskolákban eltöltött évek növekedésével, valamint a felsőoktatási expanzióval. A fiatalok egyre később alakítanak ki stabil párkapcsolatot, ezzel párhuzamosan csökken a házasság hajlandóság, valamint kitolódik az első gyermek vállalásának életkora, aminek következtében csökken a többedik gyermek megszületésének esélye. Mindehhez hozzá kell tennünk a fiatal nemzedékekben tapasztalható párkapcsolat létesítésének problémáit, a párkapcsolatok fenntartásának nehézségeit vagy az ún. kényszerszinglik számának jelentős növekedését. (Pongrácz és Spéder 2002, Demény 2004, Utasi 2004, Székely 2012, Jancsák 2013)

A megkérdezett fiatalok szembesülnek ezekkel a problémákkal szük környezetükben vagy akár társadalmi szinten, ezen felül tapasztalják a családi struktúrákban bekövetkező válságok hatásait (pl. válás, mozaik családok, egyszülös családok). Ezen tendenciák érzékelése egyértelmüvé teszi számukra, hogy a szüleik fiatalkori családalapítási mintázata a mai viszonyok között már nem egyértelmüen megvalósítható annak ellenére, hogy időközben mindössze egy generációváltás zajlott le.

\section{Szakmai és magánéleti aspiráció}

Az életút szakmai területein történt változásokat magukra nézve az esélyek növekedésével társítják. A válaszadók több, mint fele érzékeli úgy, hogy könnyebb diplomát szerezni, szintén 50\%-uk véli érdekesebbnek, kreatívabbnak a munkalehetőségeket. A felsőfokú végzettség megszerzésének esélyét - valószínüleg a pontos statisztikai adatok ismeretének hiányában - alábecsülik, hiszen a szüleik generációjában a jelentkezők kb. harmada került be a felsőoktatásba, jelenleg közel 70\%-os ez az arány. Ehhez társul az a demográfiai tény, hogy a korábbi kohorszok létszáma jóval nagyobb volt, mint a most érettségizetteké, tehát az esélyek még nagyobbak a csökkenő születésszámok mellett. (Kozma 2004, Hrubos 2006, Veroszta 2012, Polónyi 2014)

A munka világát tekintve kétségtelen, hogy szélesebb lehetőségek állnak rendelkezésre, köszönhetően elsősorban az infokommunikációs technológia rendkívüli fejlődésének. Számos új típusú szakma keletkezett, a korábbi szakmák jelentős része is megújult, átalakult, új tudástartalmak és kompetenciakövetelmények jelentek meg a munkaerőpiacon. Az elmúlt évtizedek gazdasági és társadalmi változásai, a globalizáció által generált változások ugyancsak markánsan átalakították a munkaerőpiacot. Az iskolázottsági mutatók javulásával együtt a munka világának kitágulása érthető módon sejteti a karrierlehetőségeket. Mindez kedvező társadalmi mobilitást predesztinál a fiatalok számára, harmaduk bízik a magasabb pozíció és a kedvezőbb anyagi helyzet elérésben. További $40 \%$ vélekedik úgy, hogy társadalmilag nem lesz lefelé (és felfelé sem) mobil, azaz szüleihez hasonló pozícióval, keresettel és iskolázottsággal rendelkezik majd. Ugyanakkor csupán egytizedük gondolja, hogy kevésbé lesz érdekes a munkája, tehát a munkavégzés tartalmát illetően még kedvezőbben látják saját jövőjüket. 
Nemcsak a munkaerő-piaci lehetőségek nyíltak meg a szüleik fiatal éveihez képest a megkérdezettek véleménye szerint, hanem a világ is: a válaszadók $60 \%$-a szerint az utazás, a világ megismerése jelentős lehetőséget hordoz számukra, ezzel ezt a területet rangsorolták előre a generációs esélylatolgatásban. Természetesen ez is a politikai, gazdasági változások következménye, amelyek éppen ebben a generációváltásban következtek be és teljesedtek ki. A vasfüggöny lehullásával, a szabad munkaerö-áramlással, a kényelmesebb és gyorsabb közlekedéssel párosul a kedvezőbb iskolázottság, a magasabb életszínvonal. A földrajzi mobilitás javulása egyfelöl az itt említett szabadidős tevékenységre is igaz (utazás), másfelől a világ megismerése által szerzett ismeretek, készségek (pl. kultúrák megismerése, nyelvgyakorlás, empátia stb.) a fiatalok munkavállalói mivoltát is gazdagíthatja.

Elmondható tehát, hogy a megkérdezett középiskolások a szakmai jövőjüket érintő területeket optimistán szemlélik. A tartalmas munkavégzés, a magasabb iskolai végzettség, a jobb jövedelem, a kedvezőbb pozíció, mint társadalmi mobilitásra ható tényezők, az utazási lehetőségek javulása, mint a földrajzi mobilitást elősegítő változások sora együttesen ígéretesebb jövőt rajzol a fiatalok elé, mint amit a szüleiknek lehetőségük volt bejárni a korábbi társadalmi és gazdasági viszonyok között.

Ugyanakkor a magánéletüket illetően ellentétes irányú változásokat érzékelnek: szüleikhez képest időben elhalasztott és nehezebben megvalósuló családalapítást feltételeznek. Érdekes megfigyelni, hogy a „könnyebbnek” vélt karrierút és a „nehezebbnek" gondolt magánélet viszonylatában hogyan gondolkodnak általában a boldog élet esélyeiről. A válaszadók $60 \%$-a ugyanolyan mértékü boldogságot lát esélyesnek, mint a szüleié. Tehát az ellentétes irányok a válaszadók többségénél mintegy kioltják egymást: a kedvezőbb karrieresélyek nem jelentenek feltétlenül nagyobb boldogságot a kedvezőtlenebb magánéleti esélyek miatt, és fordítva.

Ezt a gondolatmenetet tovább követve próbáltuk a megkérdezett fiatalok jövőszemléletét megragadni. Ezért egy ,jövő-indexet” hoztunk létre azoknak a változóknak a felhasználásával, amelyek a kérdőív adta lehetőségek között a magánéleti és a szakmai boldogulás megítélésére vonatkoztak. ${ }^{4} \mathrm{Az}$ index átlagát véve két csoportot alakítottunk ki, az egyiket szakmaorientáltnak, a másikat magánélet-orientáltnak neveztük el. Érdekes módon a két csoportba azonos arányba sorolódtak a válaszadók, az előbbibe 177 fó, az utóbbiba 176 fó (6 fó esetében hiányos válaszok adódtak).

A jövőorientáltság csupán a nemmel mutatott szignifikáns összefüggést, a magánélet-orientáltak 62\%-a nő ( $\mathrm{p}=0,028)$, a másik csoportban viszont egyenlő arányban oszlik meg a két társadalmi nem. Nem befolyásolta a jövő ilyen irányú megítélését az apa vagy az anya iskolai végzettsége, a település típusa, az objektív és a szubjektív anyagi helyzet. Nem találtunk kapcsolatot az iskola típusával, a tanulmányi átlaggal sem. A továbbtanulási és munkavállalási terveknél halványan kibontakozik, hogy a magánéleti eseményekben jobban bízók inkább vállalnak otthonról végezhető munkát, előnyben részesítik (a biztonságosabbnak vélt) állami szférát, saját régiójukban

\footnotetext{
${ }^{4}$ A jövő-index megalkotásánál felhasznált változók: az életcélok megítélésénél mennyire fontos a boldog családi élet (fontos és kevésbé vagy egyáltalán nem fontos), megítélése szerint mennyire esélyes a családalapításra (esélyes, nem esélyes), megítélése szerint mennyire esélyes a boldog életre (esélyes, nem esélyes).
} 
inkább látják megvalósíthatónak jövőjüket, kevésbé gondolkodnak külföldi munkavállalásban, és rövidebb idejü továbbtanulást terveznek, mint a másik alminta tagjai. A nyíregyházi kis létszámú minta nem ad lehetőséget a jövő-indexet használva mélyebb elemzésre, de figyelemre méltó kutatási irányt jelöl a nemzetközi kutatás adatbázisát tekintve.

\section{Értékek és a jövő}

A jövőbeli elvárásokat, terveket, aspirációkat számos tényező befolyásolja. Hakim (2000) a motivációk, a személyes életcélok, attitüdök és értékek jelentőségét hangsúlyozza. A kulturális jellemzők, a vizsgált társadalomban uralkodó normák, értékek, s az adott ország munkavégzéssel, tanulással vagy akár gyermekvállalással kapcsolatos intézményi és jogszabályi háttere együttesen alakítja az értékek és preferenciák rendszerét. Az egyén által preferált értékeknek egy része állandó egy másik részük azonban módosul, életkortól és családi életciklustól függően (R. Fedor 2015). Az életcélok is annak megfelelően alakulnak, hogy az egyén az adott élethelyzetben mit tart fontosnak. Később ezek a prioritások felcserélődnek (Kohli 1993), akár párhuzamosan egymás mellett futhatnak. Ennek következményeképpen az életciklushoz kapcsolódóan hol a tanuláshoz, hol a munkavállaláshoz, hol pedig a gyermekvállaláshoz kötődő értékek erősebbek.

\section{A fiatalok életcéljai}

Vizsgálatunkban a megkérdezett fiatalok életcéljaira kérdeztünk rá. Arra voltunk kíváncsiak, hogy a felsorolt 15 itemből melyet tartják nagyon fontosnak, inkább fontosnak, inkább nem fontosnak, egyáltalán nem fontosnak. (3. táblázat) A felsorolt értékek közül kiemelkedően a legtöbbek által preferált életcélok közé tartozott a boldog családi élet, melyet a válaszadók 88,3\%-a sorolt a fontos kategóriába, s szinte minden fiatal $(96,4 \%)$ tartott fontosnak, illetve inkább fontosnak. Ez a családcentrikus attitűd visszatükröződik a hazai értékvizsgálatokból (Pongráczné, S. Molnár és Dobossy 2000, Pongráczné és S. Molnár 2011) valamint, a Nyíregyháza Ifjúsága 2015 címü vizsgálatból is (R. Fedor 2016).

Hasonlóan igen magas volt még a gondok és kellemetlenségek nélküli nyugodt élet (64,3\%), valamint a képességek fejlesztése, önmegvalósitás (60,2\%), mint életcél elfogadása. A fiatalok igen jelentőségteljes, s mind emellett szinte azonos horderejü értékként tekintenek a felsőfokú végzettség megszerzésére (57,7\%) az öröm és szórakozás $(59,1 \%)$ kategóriájára, valamint a baráti kapcsolatok kialakítására $(57,4 \%)$. Utóbbi kettő az életkori sajátosságból adódó kortárscsoport kapcsolatok fontosságát hangsúlyozza. Összességében elmondhatjuk, hogy a megkérdezett fiatalok életében jelenleg a családdal, tanulmányokkal, önmegvalósítással és barátokkal kapcsolatos életcélok emelkednek ki. Ezzel szemben azt tapasztaltuk, hogy a vallási tanítások szerinti életvitel $(8,3 \%)$, a hatalombirtoklás $(13,1 \%)$, a vállalkozás alapítása $(14,3 \%)$ kerültek a fiatalok rangsorának a végére.

Kíváncsiak voltuk arra is, hogy az egyes szocio-demográfiai/szocio-kulturális tényezők közül a nem és a szülők iskolai végzettsége magyarázza-e a fiatalok életcélpreferenciáit. Nemenkénti megoszlás szerint a gondok és kellemetlenségek nélküli 
nyugodt éle ( $\mathrm{p}=0,032)$, valamint az érdekes kreatív munka életcélok $(\mathrm{p}=0,008)$ között találtunk statisztikailag releváns összefüggést. Ennek értelmében a nők számára fontosabb a nyugodt élet és kreatív munka, mint a férfiaknak. Az öt legfontosabbnak ítélt életcél fontosságáról alkotott vélemény (százalékos megoszlásban) szinte hajszálpontosan megegyezet a férfiak és a nők körében.

A szülők iskolai végzettségét külön-külön vizsgálva azt tapasztaltuk, hogy az apák iskolai végzettsége a következő életcélokat határozza meg: felsöfokú végzettség megszerzése $(\mathrm{p}=0,008)$ (minél magasabb az apa végzettsége annál inkább azonosultak a fiatalok ezzel az életcéllal), barátok szerzése ( $\mathrm{p}=0,001)$ (minél magasabb az apa végzettsége annál kevésbé fontos ez a fiatalok számára).

Az anyák iskolai végzettsége alapján, az öröm és szórakozás $(\mathrm{p}=0,002)$ és az egyéni szabadság, gondolkodási és cselekvési függetlenség $(\mathrm{p}=0,036)$ változók közötti összefüggés nyert bizonyítást. Előbbiről elmondhatjuk, hogy a középfokú végzettséget birtokló anyák gyermekei számára kevésbé fontos az öröm és a szórakozás, míg utóbbi tekintetében megállapíthatjuk, hogy az alapfokú végzettséggel rendelkező anyák gyermekei számára a legfontosabb a szabadság és a függetlenség kérdése.

\begin{tabular}{|l|c|c|c|c|c|}
\hline & $\begin{array}{c}\text { Nagyon } \\
\text { fontos }\end{array}$ & $\begin{array}{c}\text { Inkább } \\
\text { fontos }\end{array}$ & $\begin{array}{c}\text { Inkább } \\
\text { nem fontos }\end{array}$ & $\begin{array}{c}\text { Egyáltalán } \\
\text { nem fontos }\end{array}$ & $\begin{array}{c}\text { Nem tu- } \\
\text { dom/nem vá- } \\
\text { laszolok }\end{array}$ \\
\hline $\begin{array}{l}\text { Felsőfokú végzettség megszer- } \\
\text { zése }\end{array}$ & 57,7 & 34,3 & 5,4 & 1,7 & $\mathbf{0 , 9}$ \\
\hline Boldog család élet & $\mathbf{8 8 , 3}$ & 8,1 & 2,8 & 0,8 & 0,0 \\
\hline Vállalkozás alapítása & 14,3 & 38,3 & 36,8 & 9,4 & 1,2 \\
\hline Öröm és szórakozás & $\mathbf{5 9 , 1}$ & 33,4 & 4,2 & 0,6 & 2,8 \\
\hline $\begin{array}{l}\text { A képességek fejlesztése, ön- } \\
\text { megvalósítás }\end{array}$ & $\mathbf{6 0 , 2}$ & 35,9 & 2,5 & 0,8 & 0,6 \\
\hline $\begin{array}{l}\text { Gondok és kellemetlenségek } \\
\text { nélküli nyugodt élet }\end{array}$ & $\mathbf{6 4 , 3}$ & 28,4 & 5,6 & 1,7 & 0,0 \\
\hline $\begin{array}{l}\text { Anyagi javak felhalmozása és a } \\
\text { magas jövedelem }\end{array}$ & 35,3 & 49,6 & 12,6 & 2,0 & 0,6 \\
\hline $\begin{array}{l}\text { Tisztelet kivívása az emberek } \\
\text { körében }\end{array}$ & 42,3 & 44,8 & 10,3 & $\mathbf{2 , 2}$ & 0,3 \\
\hline Érdekes, kreatív munka & 44,4 & 37,6 & 14,1 & 3,4 & 0,6 \\
\hline $\begin{array}{l}\text { A vallási tanítások szerinti élet- } \\
\text { vitel }\end{array}$ & 8,3 & 22,6 & 30,3 & 38,6 & 0,3 \\
\hline $\begin{array}{l}\text { Egyéni szabadság, gondolkodási } \\
\text { és cselekvési függetlenség }\end{array}$ & 45,5 & 47,0 & 6,8 & 1,4 & 0,3 \\
\hline Segítségnyújtás az embereknek & 32,8 & 53,7 & 11,9 & 1,1 & 0,6 \\
\hline Barátok szerzése & $\mathbf{5 7 , 4}$ & 34,3 & 5,8 & 1,9 & 0,6 \\
\hline Magas társadalmi pozíció elérése & 22,9 & 44,4 & 27,1 & 5,3 & 0,3 \\
\hline Hatalombirtoklás & 13,1 & 27,8 & 37,5 & 20,7 & 0,9 \\
\hline Forfas: & & & \\
\hline
\end{tabular}

Forrás: Nyíregyházi középiskolások 2015 (N=331)

3. táblázat. Az egyes életcélok fontosságának megítélése (százalék). 


\section{A tanulók bizalmi attitüdje}

Az elmúlt évtizedekben a társadalmi tőke vizsgálata egyre inkább az érdeklődés középpontjába került. Ehhez kapcsolódóan egyre bővült azon kutatások száma melyek a társadalmi kapcsolatok szerepét vizsgálták a gazdasági aktivitás és az emberi jólét tekintetében (Imre 2001, Kun 2010). A társadalmi tőke meghatározásának négy irányvonala különböztethető meg: a közgazdaságtani, a szociológiai, a politológiai és az antropológiai. A négy meghatározás fontos kapcsolódási pontja, hogy a bizalmat a társadalmi tőke alapvető jellemzőjeként írják le (Skrabski és Kopp 2008).

\begin{tabular}{|l|c|c|c|c|c|}
\hline & $\begin{array}{c}\text { Teljesen } \\
\text { egyetértek }\end{array}$ & $\begin{array}{c}\text { Inkább } \\
\text { egyetértek }\end{array}$ & $\begin{array}{c}\text { Inkább } \\
\text { nem értek } \\
\text { egyet }\end{array}$ & $\begin{array}{c}\text { Egyáltalán } \\
\text { nem értek } \\
\text { egyet }\end{array}$ & $\begin{array}{c}\text { Nem tu- } \\
\text { dom/ } \\
\text { nem } \\
\text { válaszolok }\end{array}$ \\
\hline $\begin{array}{l}\text { A legtöbb } \\
\text { szomszédomban meg- } \\
\text { bízok }\end{array}$ & 10,6 & 37,3 & 30,4 & 16,2 & 5,5 \\
\hline $\begin{array}{l}\text { A környezetem több- } \\
\text { sége ki akar használni }\end{array}$ & 8,4 & 23,1 & 39,6 & 22,8 & 6,1 \\
\hline $\begin{array}{l}\text { Városom (falvam) la- } \\
\text { kosainak többségében } \\
\text { meg lehet bízni }\end{array}$ & 5,6 & 23,1 & 39,6 & 20,3 & 11,4 \\
\hline $\begin{array}{l}\text { Tanáraim többségé- } \\
\text { hez lehet segítségért } \\
\text { fordulni }\end{array}$ & $\mathbf{2 4 , 8}$ & $\mathbf{5 0 , 1}$ & 16,2 & 4,7 & 4,2 \\
\hline $\begin{array}{l}\text { Ha szükséges, akkor } \\
\text { számíthatok a } \\
\text { legtöbb } \\
\text { osztálytársam segít- } \\
\text { ségére }\end{array}$ & $\mathbf{2 3 , 4}$ & $\mathbf{4 1 , 5}$ & 24,2 & 7,8 & 3,1 \\
\hline $\begin{array}{l}\text { A városi (falusi) ható- } \\
\text { ság képviselöinek } \\
\text { többségében meg lehet } \\
\text { bízni }\end{array}$ & 9,2 & 24,5 & 31,2 & 17,5 & 17,6 \\
\hline
\end{tabular}

Forrás: Nyíregyházi középiskolások 2015 (N=354)

4. táblázat. A nyíregyházi középiskolások bizalmi attitűdje (százalék).

A fiatalok bizalmi attitűdjét öt állítással mértük, melyeket egy négyfokú skálán kellett értékelniük annak függvényében, hogy mennyire értenek egyet (vagy nem értenek egyet) az egyes állításokkal. Ahhoz, hogy kijelenthessük, hogy kik állnak a bizalmi rangsor élén a teljesen egyetértőket és az inkább egyetértőket összevonva kezeltük. Véleménynyilvánításuk a közvetlen környezetükhöz füződő bizalom megállapítására irányult. A kirajzolódó állításstruktúra arról árulkodik, hogy a megkérdezettek bizalma elsősorban tanáraik majd osztálytársaik irányába a legerősebb. A középiskolások háromnegyede nyilatkozott úgy, hogy számíthat tanárai segítségére, s 65\%-uk bizalommal fordul az osztálytársaihoz is. A rangsor harmadik helyén a szomszédság áll 
(48\%), ezt követi a település képviselőibe (34\%), majd a település lakóiba (29\%) vetett bizalom. Szembetűnő, hogy a fiatalok egyharmada egyetért azzal, hogy a környezete többsége ki akarja használni. A vélemények összességében azt mutatják, hogy a távolabbi helyi közösséghez kapcsolódó általános társadalmi bizalmatlanság mellett egy erős bizalmi viszony is jelen van a közvetlen informális kapcsolatokat (tanárok, osztálytársak, szomszédok) illetően. (4. táblázat)

Megvizsgáltuk, hogy egyes magyarázó változók, mint például a nem, az apa/anya iskolai végzettsége valamint az objektív és szubjektív anyagi helyzet magyarázza-e a bizalmi attitüdöt. Eredményeink szerint sem nemenkénti megbontásban, sem a szülök iskolai végzettsége, sem pedig az objektív anyagi helyzet szerint nincsen statisztikailag releváns összefüggés a bizalom kérdésével. Azonban a szubjektív anyagi helyzetet alapul véve azt tapasztaltuk, hogy azok a fiatalok, akik családjának anyagi helyzete saját megítélésük szerint - átlag feletti, jobban bíznak a helyi hatóságok képviselőiben, mint az átlag alatti jövedelmi viszonyokról beszámoló társaik.

\section{Összegzés}

A kutatás során megkérdezett nyíregyházi fiatalok jövőképét háromoldalú egységben igyekeztünk körbejárni: a szakmai és magánéleti tervek vizsgálatát kiegészítettük az értékpreferenciák elemzésével. Az eredmények alapján összességében elmondható, hogy a munkával, karrierrel összefüggő terveik világosabbak és optimistábbak, mint a magánéleti életút-elképzelés. A nagy többségében munkatapasztalattal már rendelkező diákok reálisan mérik fel lehetőségeiket a munkaerőpiacon, a szaktudásra és a szorgalomra alapoznak, az elvárható jövedelemmel tisztában vannak. Mindehhez nagyfokú optimizmus társul, bíznak abban, hogy a megszerzett iskolai végzettséggel, a rendelkezésre álló munkaerő-piaci lehetőségekkel könnyebben boldogulnak majd, mint szüleik generációja. A magánéleti jövőképük kevésbé bizakodó: leginkább boldog családi életre vágynak, ugyanakkor a privát életesemények bekövetkeztének esélyét kevesebbre becsülik a korábbi generációkhoz képest. Kapcsolataik súlypontját is elsősorban a munka világára helyezik, ismerősöktől remélve inkább segítséget, mint majdani családtagjaiktól. A két terület (munka, család) összehangolásának szándéka azonban fel-felsejlik a válaszokban, például az atipikus munkaformákat vagy a külföldi munkavállalást tekintve.

\section{Felhasznált irodalom:}

1. Balog P. (2008): A házastársi/élettársi kapcsolat szerepe az esélyteremtésben. In: Kopp Mária (szerk.): Magyar lelkiállapot 2008. Budapest, Semmelweis Kiadó, 2008. 240-249.

2. Czibere I. (2014): A települési és regionális egyenlötlenségek a 18-29 éves ifjúsági korosztály körében: Munkaeröpiac - jövőtervezés - érvényesülés. In. Másodkézből. Magyar Ifjúság 2012. 45-72.

3. Demény P. (2004): Európa népességpolitikai dilemmái a huszonegyedik század kezdetén. Demográfia 2004/ 1-2. 10-40. 
4. Engler Á. (2011): Kisgyermekes nök a felsőoktatásban. Budapest, Gondolat.

5. Fényes H. (2010): A nemi sajátosságok különbségének vizsgálata az oktatásban. A nők hátrányainak felszámolódása? Debreceni Egyetem Kiadó, Debrecen.

6. Fényes H., Kiss G. (2011): Az önkéntesség Európai Éve - Az önkéntesség társadalmi jelensége és jelentősége I. rész. Debreceni Szemle 4. 360-368.

7. Forgó M., Czakó A., Lévai R. (2009): Frissdiplomásokkal szemben támasztott munkaadó elvárások. Felsőoktatási Mühely 3. 75-86.

8. Gazsó T. (2013): Munkaerő-piaci helyzetkép. In. Székely Levente: Magyar Ifjúság 2012. 127-151.

Hakim, C. (2000): Work-lifestyle choices in the 21st century: Preference theory. Oxford University Press, London.

9. Hrubos I. (2006): A 21. század egyeteme. Educatio 4: 665-683.

10. Imre A. (2001): Emberi és/vagy társadalmi tőke. Educatio 3, 601-605. p.

11. Jancsák Cs. (2013): Ifjúsági korosztályok korszakváltásban. Budapest, Új Mandátum Könyvkiadó.

12. Kállai B., Lengyelné P.M., Nyírcsák J. (2016): Munkaerőpiac, külföldi munka és tanulás. Acta Medicinae et Sociologica 7 (20-21), 48-81.

13. Kiss I., Répáczky R. (2012): Új készségek és munkahelyek: a kompetencia megközelítésére épülő szolgáltatások szerepe a foglalkoztathatóság javításában. Munkaerőpiacorientált felsőoktatás. Ötletek, bevált gyakorlatok az „Új készségek és munkahelyek" nevü európai kezdeményezéshez. Budapest, Tempus Közalapítvány.

14. Kohli, M. (1993): A foglalkozási életút intézményesülése és individualizálódása. Replika 9-10, 161-177.

15. Kopp M., Skrabski Á. (1995): Alkalmazott magatartástudomány. A megbirkózás egyéni és társadalmi stratégiái. Budapest, Corvinus Kiadó.

16. Kozma T. (2004): Kié az egyetem? A felsőoktatás nevelésszociológiája. Budapest, Új Mandátum Könyvkiadó.

17. Kóródi M. (2006): Munkaértékek vizsgálata egyetemi és főiskolai hallgatók körében. In. Juhász Erika (szerk.): Régió és oktatás. A „Regionális Egyetem” kutatás záró konferenciájának tanulmánykötete. Debrecen: Doktoranduszok Kiss Árpád Közhasznú Egyesülete, 289-322.

18. Kóródi M. (2007): Munkaértékek vizsgálata két felsőoktatási intézményben. In. Education 16. (2): 311-322.

19. Kun, A. I. (2010): A társadalmi tőke elméletei és szerepe a gazdasági folyamatokban. In: Kotsis Á.; Polónyi I. (szerk.): Innováció és felsőoktatás, Competitio 8. $158-170$.

20. Markos V. (2016a): Az önkéntes és fizetett munkát végző hallgatók családi hátterének és munkaérték preferenciáinak vizsgálata. Megjelenés alatt.

21. Markos V. (2016b): Közösségi szolgálat vagy önkéntesség. Megjelenés alatt.

22. Pikó B. (2003): Kultúra, társadalom és lélketan. Budapest, Akadémaii Kiadó.

23. Polónyi I. (2014): Régi, új felsőoktatási expanzió. Educatio, 2, 185-204.

24. Pongrácz T., S. Molnár E. (2011): A nemi szerepmegosztásról, a családi élet és a munka összhangjáról alkotott vélemények változása 2000-2009 között. In: 
Pongrácz Tiborné (szerk): A családi értékek és a demográfiai magatartás változásai. Kutatási jelentések 91. KSH Népességtudományi Kutató Intézet, Budapest, 95-112. p.

25. Pongrácz T., S. Molnár E., Dobossy I. (2000): Család és munka - értékek és aggodalmak a rendszerváltozás után. Kutatási jelentések 62. KSH NKI, Budapest.

26. Putman, R. (2000): Bowling alone: The Collapse and Revival of American Community. New York: Simon \& Schuster.

27. Rimler, J. (1999): A munka jövője: Új fogalmak, feltételek, forgatókönyvek. Közgazdasági Szemle. XLVI. évf., 1999. szeptember 772-788.

28. R. Fedor A. (2015): Egyensúlyban? A munkaerö-piaci karriertől a familiarizmusig. A kisgyermeket nevelő nők munkavállalási attitüdje(i). Debrecen: Debreceni Egyetemi Kiadó, 2015. 252 p.

29. R. Fedor A. (2016): Családalapítás és gyermekvállalás a fiatalok körében. Acta Medicinae et sociologica 7 (20-21). 11-2.

30. R. Fedor A., Balogh E. (2015): A foglalkoztatás és a munkanélküliség jellemzői a Nyíregyházi járásban In. Acta Medicinae et Sociologica 6:(18-19) pp. 47-67.

31. Skrabski Á., Kopp, M. (2008): A bizalom mint a társadalmi tőke központi jellemzője. http://vigilia.hu/regihonlap/2008/10/skrabski.htm Letöltve: 2016. 06. 23.

32. Székely L. (szerk.) 2012. Magyar ifjúság 2012. Budapest, Kutatópont.

33. Utasi Á. (2004): Feláldozott kapcsolatok. A magyar szingli. Budapest, MTA Politikai Tudományok Intézete.

34. Veroszta Zs. (2012): A felsöoktatás különbözö szintjeire felvettek jellemzöi. In: Szemerszki M. (ed.) Az érettségitől a mesterképzésig. Továbbtanulás és szelekció. Budapest, Oktatáskutató és Fejlesztő Intézet. 51-82. 